\title{
Synthesis of Moracin C and Its Derivatives with a 2-arylbenzofuran Motif and Evaluation of Their PCSK9 Inhibitory Effects in HepG2 Cells
}

\author{
Jagadeesh Nagarajappa Masagalli ${ }^{+} \mathbb{D}$, Melanayakanakatte Kuberappa BasavanaGowda ${ }^{\dagger}$, Hee-Sung Chae \\ and Won Jun Choi *iD \\ College of Pharmacy and Integrated Research Institute for Drug Development, Dongguk University, \\ Seoul 04620, Korea; mnjagadeesh123@gmail.com (J.N.M.); basavanagowdru@gmail.com (M.K.B.); \\ chaeheesung83@gmail.com (H.-S.C.) \\ * Correspondence: mp89@dongguk.edu; Tel.: +82-31-961-5219 \\ + These authors contributed equally to this work.
}

check for

updates

Citation: Masagalli, J.N.; BasavanaGowda, M.K.; Chae, H.-S.; Choi, W.J. Synthesis of Moracin

$\mathrm{C}$ and Its Derivatives with a

2-arylbenzofuran Motif and Evaluation of Their PCSK9 Inhibitory Effects in HepG2 Cells. Molecules 2021, 26, 1327. https://doi.org/ $10.3390 /$ molecules 26051327

Academic Editor: Luisella Verotta

Received: 19 January 2021

Accepted: 25 February 2021

Published: 2 March 2021

Publisher's Note: MDPI stays neutral with regard to jurisdictional claims in published maps and institutional affiliations.

Copyright: (c) 2021 by the authors. Licensee MDPI, Basel, Switzerland. This article is an open access article distributed under the terms and conditions of the Creative Commons Attribution (CC BY) license (https:// creativecommons.org/licenses/by/ $4.0 /)$.

\begin{abstract}
Proprotein convertase subtilisin/kexin type 9 (PCSK9) is a key factor in several cardiovascular diseases, as it is responsible for the elevation of circulating low-density lipoprotein cholesterol (LDL-C) levels in blood plasma by direct interaction with the LDL receptor. The development of orally available drugs to inhibit this PCSK9-LDLR interaction is a highly desirable objective. Here, we report the synthesis of naturally occurring moracin compounds and their derivatives with a 2-arylbenzofuran motif to inhibit PCSK9 expression. In addition, we discuss a short approach involving the three-step synthesis of moracin $C$ and a divergent method to obtain various analogs from one starting material. Among the tested derivatives, compound 7 (97.1\%) was identified as a more potent inhibitor of PCSK9 expression in HepG2 cells than berberine (60.9\%). These results provide a better understanding of the structure-activity relationships of moracin derivatives for the inhibition of PCSK9 expression in human hepatocytes.
\end{abstract}

Keywords: proprotein convertase subtilisin/kexin type 9; low-density lipoprotein cholesterol; cardiovascular diseases; moracin compounds; structure activity relationships; HepG2 cell lines

\section{Introduction}

Cardiovascular diseases (CVDs) are one of the leading causes of death worldwide [1] and are caused by various cardiovascular factors [2], including the elevation of circulating low-density lipoprotein cholesterol (LDL-C) levels. Proprotein convertase subtilisin/kexin type 9 (PCSK9) plays an important role in regulating the circulating levels of LDL-C due to its ability to inhibit LDL receptor recycling in the liver [3]. The loss-of-function of PCSK9 in humans significantly lowers LDL-C levels and CVD-related morbidity, which indicates that PCSK9 could be a promising therapeutic target for the treatment of CVDs by lowering LDL-C levels [4]. Thus, PCSK9 inhibition has become the focus for the treatment of hypercholesterolemia.

Owing to the promise of their therapeutic potential, multiple PCSK9 monoclonal antibodies (mAbs) have been evaluated in clinical trials. Among these antibodies, two PCSK9 mAbs (alirocumab and evolocumab) have been approved by the United States Food and Drug Administration for the treatment of coronary heart disease. In addition, a small interfering RNA medication, inclisiran, which inhibits the synthesis of PCSK9, lowered LDL-C levels in patients with CVD and is in the process of being approved [5]. However, these drugs are costly and administered by injection only, which may restrict their clinical use. Therefore, an orally available small molecule targeting PCSK9 would be a highly desirable alternative therapeutic agent, based on its ease of administration and lower cost.

Small molecules targeting PCSK9-PF-06446846 analogs-identified by Pfizer have been found to lower the secretion of PCSK9 [6]. Natural products, such as berberine, ery- 
braedin $\mathrm{D}$, sauchinone, and 3,7,2'-trihydroxy-5-methoxy-flavanone, also exhibited potent inhibitory effects on PCSK9 levels in HepG2 cells [7-9] (Figure 1). Recently, moracin C (Figure 2), the bioactive ingredient of dried, immature Morus alba fruits, was reported to downregulate PCSK9 expression in HepG2 cells [10].<smiles>O=C(c1ccc(-n2nnc3cccnc32)cc1)N(c1ncccc1Cl)C1CCCNC1</smiles>

PF-06446846<smiles>COc1ccc2cc3c(cc2c1OC)CCN1CCC3=CC1=CO</smiles>

Berberine<smiles>CC(C)=CCc1c(O)ccc2c1OC[C@@H]1c3ccc4c(c3O[C@H]21)OC(C)(C)C=C4</smiles>

Erybraedin D<smiles>C[C@H]1C[C@H]2C(=O)C=C3OCO[C@@]34C[C@H]1[C@H]2c1cc2c(cc1O4)OCO2</smiles>

Sauchinone<smiles>COc1cc(O)cc2c1C(=O)C(O)C(c1ccccc1O)O2</smiles>

3,7,2'-trihydroxy-5-methoxy-flavanone

Figure 1. Small molecule inhibitors of proprotein convertase subtilisin/kexin type 9 (PCSK9) expression.<smiles>CC(C)=CCc1c(O)cc(-c2cc3ccc(O)cc3o2)cc1O</smiles>

Figure 2. Structure of moracin C.

Herein, we describe the preparation of a new series of 2-arylbenzofuran derivatives with PCSK9 inhibitory activity by chemical modifications of moracin $\mathrm{C}$ and the screening of a library of our synthesized small molecules using PCSK9 expression in HepG2 cells as the readout.

\section{Results and Discussion}

\subsection{Design and Synthesis of Moracin Derivatives}

The retrosynthetic approach for moracin $C$ is outlined in Figure 3. We envisaged that the aliphatic chain in moracin C (1) could be easily introduced by prenylation using $n$-BuLi and prenyl halide, and the construction of the benzofuran skeleton (2, moracin M) $[11,12]$ could be achieved by the Sonogashira coupling of halobenzene-diol (3) with ethynylbenzene-diol (4).<smiles>CC(C)=CCc1c(O)cc(-c2cc3ccc(O)cc3o2)cc1O</smiles>

1 (Moracin C)<smiles>Oc1cc(O)cc(-c2cc3ccc(O)cc3o2)c1</smiles>

2

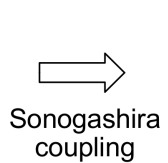
coupling 2<smiles>Oc1ccc(I)c(O)c1</smiles>

3<smiles>C#Cc1cc(O)cc(O)c1</smiles>

4

Figure 3. Retrosynthetic analysis of moracin C.

The formation of the 2-arylbenzofuran nucleus was easily accessible through the Sonogashira coupling reaction of 2-iodo-5-methoxyphenol 5 with 1-ethynyl-3,5-dimethoxybenzene 6 in the presence of $\mathrm{PdCl}_{2}\left(\mathrm{PPh}_{3}\right)_{2}$ and $\mathrm{CuI}$ in dimethylformamide (DMF). The yield of the Sonogashira product was higher $(62 \%)$ than that reported previously [13]. Prenylation of the 2-arylbenzofuran nucleus 7 was carried out using $n$-BuLi to afford a mixture of three components: a $4^{\prime}$-prenylated compound $8(25 \%)$, an isomeric 7-prenylated derivative 9 $(12 \%)$, and a di-prenylated compound 10 (15\%) (Scheme 1). 


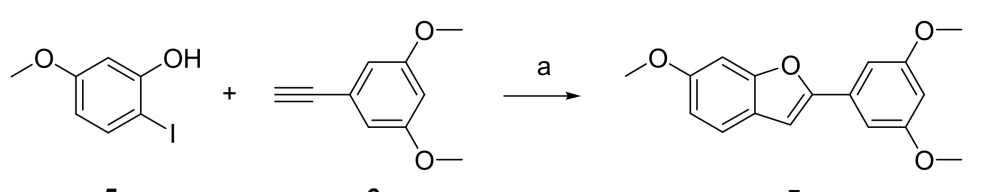

6

7

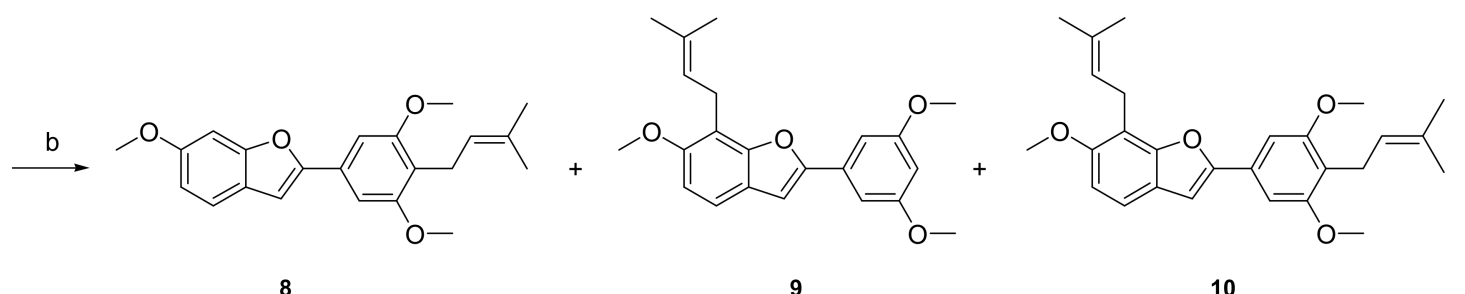

10

Scheme 1. Reagents and Conditions: (a) $\mathrm{PdCl}_{2}\left(\mathrm{PPh}_{3}\right)_{2}, \mathrm{CuI}, \mathrm{TEA}, \mathrm{DMF}, 100{ }^{\circ} \mathrm{C}, 15 \mathrm{~h}$ and (b) $2.5-\mathrm{M} n$-BuLi in hexanes, 3,3-dimethylallyl bromide, cyclohexane, $0{ }^{\circ} \mathrm{C}$ to reflux, $2 \mathrm{~h}$.

Several attempts were made for the demethylation of the methyl ether groups in compound 8 to give moracin $\mathrm{C}(\mathbf{1})$ by employing various conditions (such as $\mathrm{BBr}_{3}, \mathrm{BCl}_{3}$, $\mathrm{AlCl}_{3}$, and pyridinium $p$-toluenesulfonate (PPTS)) (Scheme 2) [14]. However, most attempts failed, resulting in the cyclized/chromane product $\mathbf{1 1}$ as the major product (Table 1).<smiles>COc1ccc2cc(-c3cc(OC)c(CC=C(C)C)c(OC)c3)oc2c1</smiles>

8

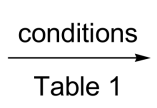

Table<smiles>CC(C)=CCc1c(O)cc(-c2cc3ccc(O)cc3o2)cc1O</smiles>

1 (Moracin C)<smiles>CC1(C)CCc2c(O)cc(-c3cc4ccc(O)cc4o3)cc2O1</smiles>

11 (Wittifuran D)

Scheme 2. Demethylation of phenolic ether.

Table 1. Reaction conditions for demethylation *

\begin{tabular}{|c|c|c|c|c|c|c|c|}
\hline \multirow[b]{2}{*}{ Entries } & \multirow[b]{2}{*}{ Conditions } & \multirow[b]{2}{*}{ Additives } & \multirow[b]{2}{*}{ Solvents } & \multirow{2}{*}{ Temp $\left({ }^{\circ} \mathrm{C}\right)$} & \multirow[b]{2}{*}{ Time (h) } & \multicolumn{2}{|c|}{ Yields (\%) } \\
\hline & & & & & & 1 & 11 \\
\hline 1 & $\mathrm{BBr}_{3}$ & - & $\mathrm{CH}_{2} \mathrm{Cl}_{2}$ & -78 to $\mathrm{rt}$ & 3 & - & 60 \\
\hline 2 & $\mathrm{BCl}_{3}$ & - & $\mathrm{CH}_{2} \mathrm{Cl}_{2}$ & -78 & 4 & - & 42 \\
\hline 3 & $\mathrm{AlCl}_{3}$ & Thiourea & $\mathrm{CH}_{2} \mathrm{Cl}_{2}$ & 50 & 4 & - & - \\
\hline 4 & $n-\mathrm{BuLi}$ & Diphenyl phosphine & THF & -78 to reflux & 36 & 10 & - \\
\hline 5 & Sodium mercaptan & 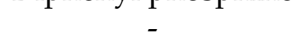 & DMF & 60 & 5 & - & - \\
\hline 6 & PPTS & - & DMF & 120 & $15 \min$ & - & 35 \\
\hline 7 & Pyridine $\cdot \mathrm{HCl}$ & - & DMF & 200 & 3 & - & 40 \\
\hline 8 & $\mathrm{NaOH}$ & 1-Dodecane thiol & NMP & 130 & 24 & 30 & - \\
\hline
\end{tabular}

* THF: tetrahydrofuran; NMP: $N$-methylpyrrolidone; Bold aims to highlight the good result.

The use of acidic reagents leads to a ring-fused/chromane formation due to the stability of the tertiary carbocation species. Interestingly, the cyclized/chromane compound 11 was found to be Wittifuran D, a natural compound present in the stem bark of Morus wittiorum (Moraceae) [15]. As a member of the library of moracin derivatives, Wittifuran D (11) was easily prepared by demethylation using a conventional reagent, $\mathrm{BBr}_{3}$, and this method also yielded moracin M (2) from 7.

Among the conditions presented in Table 1, a basic demethylation condition [16] using 1-dodecanethiol and $\mathrm{NaOH}$ in NMP met our objective in spite of the low yield and a product mixture consisting of 1 (30\%), $12(14 \%)$, and $13(10 \%)$. Compound 12 was found to be a natural compound, Artoindonesianin O [17] (Scheme 3). The methyl group in 
the partially demethylated compound, Artoindonesianin $\mathrm{O}$ (12), is present at the ortho position to the prenyl group, which was confirmed by a two-dimensional nuclear magnetic resonance (NMR) analysis.

$7 \stackrel{a}{\longrightarrow}$<smiles>Oc1cc(O)cc(-c2cc3ccc(O)cc3o2)c1</smiles>

2 (Moracin M)

$8 \stackrel{\mathrm{a}}{\longrightarrow}$<smiles>CC1(C)CCc2c(O)cc(-c3cc4ccc(O)cc4o3)cc2O1</smiles>

11 (Wittifuran D)

$8 \stackrel{b}{\longrightarrow}$<smiles>CC(C)=CCc1c(O)cc(-c2cc3ccc(O)cc3o2)cc1O</smiles>

1 (Moracin C)<smiles>COc1cc(-c2cc3ccc(O)cc3o2)cc(O)c1CC=C(C)C</smiles>

12 (Artoindonesianin O)<smiles>COc1cc(-c2cc3ccc(O)cc3o2)cc(OC)c1CC=C(C)C</smiles>

13

$9 \stackrel{\mathrm{b}}{\longrightarrow}$<smiles>CC(C)=CCc1c(O)ccc2cc(-c3cc(O)cc(O)c3)oc12</smiles>

14 (Moracin S)<smiles>COc1ccc2cc(-c3cc(O)cc(O)c3)oc2c1CC=C(C)C</smiles>

15<smiles>CC(C)=CCc1c(O)cc(-c2cc3ccc(O)c(CC=C(C)C)c3o2)cc1O</smiles>

16 (Morusalfuran D)<smiles>COc1ccc2cc(-c3cc(O)c(CC=C(C)C)c(O)c3)oc2c1CC=C(C)C</smiles>

17

Scheme 3. Reagents and conditions: (a) 1.0- $\mathrm{M} \mathrm{BBr}_{3}, \mathrm{CH}_{2} \mathrm{Cl}_{2},-78^{\circ} \mathrm{C}$ to room temperature (rt), $3 \mathrm{~h}$ and (b) 1-dodecanethiol, $\mathrm{NMP}, \mathrm{NaOH}, 130^{\circ} \mathrm{C}, 24 \mathrm{~h}$.

A similar method was applied to the intermediate compounds 9 and 10, resulting in fully deprotected final products 14 (moracin S) [18] and 16 (morusalfuran D) [19] and two new partially deprotected moracin derivatives, 15 and 17 (Scheme 3).

\subsection{Inhibitory Activity against PCSK9 mRNA Expression}

The inhibitory effects of a series of synthesized Moracin $C$ and its derivatives on PCSK9 mRNA was measured by quantitative RT-PCR using human hepatoma HepG2 cells (Figure 4A). 


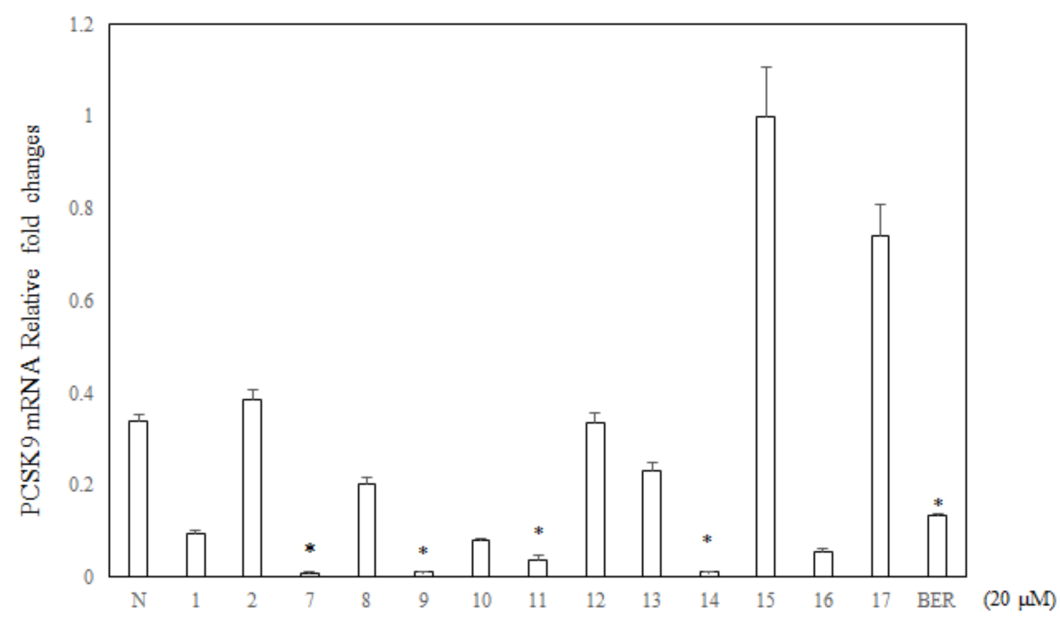

(A)

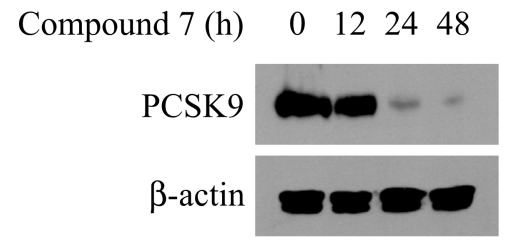

(B)

Figure 4. Identification of compound 7 as a strong inhibitor of PCSK9. (A) Evaluation of the PCSK9 mRNA level by quantitative RT-PCR. The expression of PCSK9 mRNA was measured in HepG2 cells after the treatment of compounds $(20 \mu \mathrm{M})$ and berberine. $\mathrm{HCl}(\mathrm{BER} ; 20 \mu \mathrm{M})$ for $24 \mathrm{~h}$. Mean values of three independent experiments are shown, and the asterisk $\left(^{*}\right)$ indicates $p<0.05$. (B) Western blot analysis indicates that compound 7 inhibited the expression of PCSK9 in HepG2 cells.

Among them, 1, 7, 9, 11, and $\mathbf{1 4}$ were found to significantly inhibit the expression of PCSK9 mRNA, whose percent inhibitory activities were $44.9 \%, 97.1 \%, 96.7 \%, 88.5 \%$, and $96.3 \%$ (berberine $60.9 \%$ ), respectively. However, other compounds failed to exhibit suppressive effects. In particular, compound 7 , the protected Moracin C precursor without a prenyl group, exhibited the strongest inhibitory effect. To confirm whether compound 7 can downregulate the expression of PCSK9, we exposed compound 7 to HepG2 cells, conducted a Western blot analysis, and found that compound 7 suppressed the expression of PCSK9 protein (Figure 4B).

In conclusion, the present approach to synthesize moracin $C$ in three steps was found to be more efficient than those reported previously in terms of both yield and time [20,21]. The exclusive scale-up synthesis of the other natural products presented herein will be reported in the near future. Various prenylated 2-arylbenzofuran derivatives could exert more persistent and enhanced biological effects than moracin C.

The results of the present study provide a better understanding of the structureactivity relationships of moracin derivatives for the inhibition of PCSK9 expression in human hepatocytes. This information would be useful for the rational design of new drugs for hypercholesterolemia.

\section{Materials and Methods}

\subsection{Figures, Tables, and Schemes}

Except where noted, all the materials were purchased from commercial suppliers (Sigma Aldrich, Darmstadt, Germany; Tokyo Chemical Industy Co., ltd. Tokyo, Japan; Alfa, Ward Hill, MA, USA; Combi-blocks, San Diego, CA, USA) and were used without further purification. All reactions were routinely carried out under an inert atmosphere of dried nitrogen. ${ }^{1} \mathrm{H}-\mathrm{NMR}$ spectra $\left(\mathrm{CDCl}_{3}, \mathrm{CD}_{3} \mathrm{OD}\right.$, and $\left.\left(\mathrm{CD}_{3}\right)_{2} \mathrm{CO}\right)$ were recorded on a Varian (400 MHz) spectrometer (Varian Medical Systems, Inc., Palo Alto, CA, USA). The ${ }^{1} \mathrm{H}-\mathrm{NMR}$ data are reported as peak multiplicities: $\mathrm{s}$ for singlet, $\mathrm{d}$ for doublet, $\mathrm{dd}$ for doublet of doublets, $\mathrm{t}$ for triplet, $\mathrm{q}$ for quartet, bs for broad singlet, and $\mathrm{m}$ for multiplet. ${ }^{13} \mathrm{C}$-NMR spectra $\left(\mathrm{CDCl}_{3}, \mathrm{CD}_{3} \mathrm{OD}\right.$, and $\left.\left(\mathrm{CD}_{3}\right)_{2} \mathrm{CO}\right)$ were recorded on a Varian $(100 \mathrm{MHz})$ spectrometer (Palo Alto, CA, USA). The chemical shifts are reported as parts per million $(\delta)$ relative to the solvent peak, with the coupling constants in hertz $(\mathrm{Hz})$. Infrared spectra were recorded on Fourier-transform infrared spectroscopy (FTIR, NICOLET-iS5, Waltham, MA, 
USA). Reactions were monitored with Thin-layer chromatography (TLC, Merck precoated 60 F254 plates, Darmstadt, Germany). Spots were detected by viewing under a UV light and colorizing with charring after dipping in $\mathrm{KMnO}_{4}$ solution. Column chromatography was performed on silica gel 60 (230-400 mesh Kieselgel 60). Purity of the final compound was determined using reversed-phase high-pressure liquid chromatography (RP-HPLC) performed on a Waters Corp. HPLC system equipped with an ultraviolet (UV) detector at $254 \mathrm{~nm}$ operating at $25^{\circ} \mathrm{C}$. The HPLC employed a YMC hydrosphere C18 (HS-302) column (5- $\mu \mathrm{m}$ particle size and 12-nm pore size) with a diameter of $4.6 \mathrm{~mm}$ and length of $150 \mathrm{~mm}$ at a flow rate of $1.0 \mathrm{~mL} / \mathrm{min}$. Mobile phase: (A) $\mathrm{H}_{2} \mathrm{O}$ containing $0.05 \%$ trifluoroacetic acid and (B) $\mathrm{CH}_{3} \mathrm{CN}$. Method I: a gradient of $25 \% \mathrm{~B}$ to $100 \% \mathrm{~B}$ in $30 \mathrm{~min}$ and Method II: a gradient of $50 \%$ B to $100 \%$ B in $30 \mathrm{~min}$. (The purity data are provided in Supplementary Materials.) The purity of all tested compounds was $>95 \%$ purity using Method I and Method II. The mass spectra were recorded using LRMS (electron ionization Mass spectrometry (MS)) obtained on a Shimadzu-2020 or using HRMS (electrospray ionization MS) obtained on a G2 Quadrupole time-of-flight (QTOF) mass spectrometer.

\subsection{Cell Culture, Drugs and Chemicals}

HepG2 human hepatocellular cells were obtained from the Korea Research Institute of Bioscience and Biotechnology (KRIBB, Daejeon, Korea) and grown in Eagle's Minimum Essential Media (EMEM) containing 10\% fetal bovine serum and $100-\mathrm{U} / \mathrm{mL}$ penicillin/streptomycin (Pen/Strep). Cells were cultured in a humidified incubator with $5 \% \mathrm{CO}_{2}$ at $37^{\circ} \mathrm{C}$. EMEM and Pen/Strep were purchased from Hyclone (Logan, UT, USA). Bovine serum albumin (BSA) was purchased from Sigma-Aldrich (St. Louis, MO, USA). Antibodies against PCSK9 and $\beta$-actin were purchased from Abcam (Cambridge, MA, USA).

\subsection{Quantitative Real-Time RT-PCR}

Total RNA was isolated using a Trizol RNA extraction kit (Thermo Fisher Korea, Seoul, Korea) according to the manufacturer's instructions. Briefly, total RNA (1 $\mu \mathrm{g})$ was converted to Complementary DNA (cDNA) by reverse transcriptase (200 unit) and oligodeoxythymidine triphosphate (dT) primer $(500 \mathrm{ng})$ in $50-\mathrm{mM}$ Tris- $\mathrm{HCl}(\mathrm{pH} 8.3), 75-\mathrm{mM}$ $\mathrm{KCl}, 3-\mathrm{mM} \mathrm{MgCl}_{2}, 10-\mathrm{mM}$ dithiothreitol (DTT), and 1-mM deoxyribose Nucleoside Triphosphates (dNTPs) at $42{ }^{\circ} \mathrm{C}$ for $1 \mathrm{~h}$. The reaction was terminated by incubating the solution at $70{ }^{\circ} \mathrm{C}$ for $15 \mathrm{~min}$; after which, $1-\mu \mathrm{l} \mathrm{cDNA}$ mixture was mixed for PCR amplification. PCR reaction was performed using $1-\mu \mathrm{L} c \mathrm{DNA}$ and $9-\mu \mathrm{L}$ master mix containing $\mathrm{iQ}$ SYBR Green Supermix (Bio-Rad, Hercules, CA, USA), forward primer ( 5 pmol), and reverse primer (5 pmol) in a CFX384 Real-Time PCR Detection System (Bio-Rad, Hercules, CA, USA). PCR reaction was as follow: $3 \mathrm{~min}$ at $95^{\circ} \mathrm{C}$, followed by 40 cycles of $95^{\circ} \mathrm{C}$ for $10 \mathrm{sec}, 55^{\circ} \mathrm{C}$ for $30 \mathrm{sec}$, and $72{ }^{\circ} \mathrm{C}$ for $2 \mathrm{~min}$. The fluorescence signal generated by SYBR Green I DNA dye was measured. PCR primers were obtained from Bioneer (Daejeon, Korea), and the specificity of the primers was confirmed using the melting curve analysis. Data were collected and managed by CFX Manager Software (Bio-Rad, Hercules, CA, USA). The sequences of the PCR primer sets were as follows: human PCSK9 (Forward: GGTACTGACCCCCAACCTG and Reverse: CCGAGTGTGCTGACCATACA) and human Glyceraldehyde 3-phosphate dehydrogenase (GAPDH) (Forward: GAAGGTGAAGGTCGGAGTCA and Reverse: AATGAAGGGGTCATTGATGG).

\subsection{Statistical Analysis}

The data from the experiments were expressed as the mean \pm S.E.M. The level of statistical significance was determined by analysis of variance (ANOVA), followed by Dunnett's $t$-test for multiple comparisons. $P$-values less than 0.05 were regarded as statistically significant. 


\subsection{Western Blot Analysis}

Sample were ground by pestle and incubated with 200- $\mu$ L RIPA buffer (50-mM Tris$\mathrm{HCl}$ at $\mathrm{pH} 8.0,150-\mathrm{mM} \mathrm{NaCl}, 1 \% \mathrm{NP}-40,0.5 \%$ sodium deoxycholate, and protease inhibitors cocktail) for $1 \mathrm{~h}$ on ice. Lysates were collected by centrifugation, and protein concentration was measured by the BCA Protein Assay Kit (Thermo Fisher, Pittsburgh, PA, USA). Equal amounts of lysates were resolved by SDS-PAGE and transferred to the Polyvinylidene fluoride (PVDF) membrane. The membrane was incubated in blocking buffer (5\% skim milk in $1 \times$ PBS- $0.1 \%$ Tween-20; PBST) for $1 \mathrm{~h}$ and hybridized with the appropriate primary antibody in $1 \times$ PBS containing $3 \%$ bovine serum albumin (BSA) overnight at $4{ }^{\circ} \mathrm{C}$. After washing three times with $1 \mathrm{x}$ PBST for $30 \mathrm{~min}$, the membrane was hybridized with the appropriate Horseradish peroxidase (HRP)-conjugated secondary antibody (Cell Signaling Technology, Danvers, MA, USA) for $1 \mathrm{~h}$ at room temperature and washed three times with 1x PBST solution for $30 \mathrm{~min}$. The membrane was visualized using an enhanced chemiluminescence (ECL) detection system.

\subsection{Synthetic Methods}

2-(3,5-Dimethoxyphenyl)-6-methoxybenzofuran (7): To a stirred solution of 2-iodo-5 -methoxyphenol $5(1 \mathrm{~g}, 4.2 \mathrm{mmol})$ in dry DMF $(8 \mathrm{~mL})$ under $\mathrm{N}_{2}$ atmosphere were added successively $\mathrm{PdCl}_{2}\left(\mathrm{PPh}_{3}\right)_{2}(148 \mathrm{mg}, 0.21 \mathrm{mmol}), \mathrm{CuI}(27 \mathrm{mg}, 0.25 \mathrm{mmol})$, and $\mathrm{Et}_{3} \mathrm{~N}(1.8 \mathrm{~mL}$, $12.6 \mathrm{mmol})$. After $5 \mathrm{~min}$, 1-ethynyl-3,5-dimethoxybenzene 6 ( $1 \mathrm{~g}, 6.3 \mathrm{mmol})$ was added, and the mixture was stirred at $80^{\circ} \mathrm{C}$ for $15 \mathrm{~h}$. The reaction mixture was cooled to room temperature and acidified with dilute $\mathrm{HCl}$ and extracted with ethyl acetate. The organic layer was washed with water, then dried over $\mathrm{MgSO}_{4}$, filtered, and evaporated. The residue was purified by silica gel column chromatography (Hex:EtOAc $=9: 1, v / v)$ to afford compound 7 (750 mg, 62\% yield) as a pale yellow solid: ${ }^{1} \mathrm{H}-\mathrm{NMR}\left(400 \mathrm{MHz}, \mathrm{CDCl}_{3}\right) \delta 7.40$ $(\mathrm{d}, J=8.8 \mathrm{~Hz}, 1 \mathrm{H}), 7.05(\mathrm{~d}, J=2.4 \mathrm{~Hz}, 1 \mathrm{H}), 6.95(\mathrm{~d}, J=2.4 \mathrm{~Hz}, 2 \mathrm{H}), 6.91(\mathrm{~d}, J=0.8 \mathrm{~Hz}, 1 \mathrm{H})$, $6.85(\mathrm{dd}, J=2.0$ and $8.4 \mathrm{~Hz}, 1 \mathrm{H}), 6.43(\mathrm{t}, J=2.0 \mathrm{~Hz}, 1 \mathrm{H}), 3.84(\mathrm{~s}, 3 \mathrm{H}), 3.83(\mathrm{~s}, 6 \mathrm{H}) ;{ }^{13} \mathrm{C}-\mathrm{NMR}$ $\left(100 \mathrm{MHz}, \mathrm{CDCl}_{3}\right) \delta 161.07,158.15,155.82,154.90,132.43,122.42,121.06,112.03,102.50$, 101.71, 100.54, 95.80, 55.69, 55.67, 55.44, 55.42; IR (neat) 2935, 2829, 1598, 1444, 1204, 1137, $810 \mathrm{~cm}^{-1}$; LCMS Electrospray ionization (ESI) $\mathrm{m} / z$ calcd for $\mathrm{C}_{17} \mathrm{H}_{17} \mathrm{O}_{4}[\mathrm{M}+\mathrm{H}]^{+}:$: 285.1127, found: 285.1139; Purity 96.21\% (determined by RP-HPLC, method I, $t_{\mathrm{R}}=21.64 \mathrm{~min}$ ).

\subsubsection{Procedure for Prenylation}

$n$-Butyllithium (1.6 M solution in hexane, $1.64 \mathrm{~mL}, 2.63 \mathrm{mmol}$ ) was added dropwise to a stirred solution of $7(500 \mathrm{mg}, 1.75 \mathrm{mmol})$ in absolute cyclohexane $(15 \mathrm{~mL})$ at $0{ }^{\circ} \mathrm{C}$ under $\mathrm{N}_{2}$ atmosphere. The reaction mixture was heated at $60{ }^{\circ} \mathrm{C}$ for $30 \mathrm{~min}$. After cooling to room temperature, 3,3-dimethylallylbromide $(0.3 \mathrm{~mL}, 2.63 \mathrm{mmol})$ was added dropwise, and the resulting mixture was stirred at $60^{\circ} \mathrm{C}$ for $2 \mathrm{~h} \mathrm{[22].} \mathrm{The} \mathrm{reaction} \mathrm{mixture} \mathrm{was} \mathrm{cooled}$ and poured into a saturated solution of sodium bicarbonate, extracted with ethyl acetate, washed with water, dried over $\mathrm{MgSO}_{4}$, filtered, and evaporated. The crude residue was purified by column chromatography (Hex:EtOAc $=9.5: 0.5, v / v)$ to get the products 8, 9, and 10.

6-Methoxy-2-(3,5-dimethoxy-4-(3-methylbut-2-enyl)phenyl)benzofuran (8): $154 \mathrm{mg}$ (25\% yield) as a white solid: ${ }^{1} \mathrm{H}-\mathrm{NMR}\left(400 \mathrm{MHz}, \mathrm{CDCl}_{3}\right) \delta 7.42(\mathrm{~d}, J=8.4 \mathrm{~Hz}, 1 \mathrm{H}), 7.08(\mathrm{bs}, 1 \mathrm{H}), 6.98$ $(\mathrm{s}, 2 \mathrm{H}), 6.91(\mathrm{~s}, 1 \mathrm{H}), 6.86(\mathrm{dd}, J=1.6$ and $8.8 \mathrm{~Hz}, 1 \mathrm{H}), 5.20(\mathrm{t}, J=7.2 \mathrm{~Hz}, 1 \mathrm{H}), 3.90(\mathrm{~s}, 6 \mathrm{H})$, $3.87(\mathrm{~s}, 3 \mathrm{H}), 3.36(\mathrm{~d}, J=6.8 \mathrm{~Hz}, 2 \mathrm{H}), 1.78(\mathrm{~s}, 3 \mathrm{H}), 1.67(\mathrm{~s}, 3 \mathrm{H}) ;{ }^{13} \mathrm{C}-\mathrm{NMR}\left(100 \mathrm{MHz}, \mathrm{CDCl}_{3}\right) \delta$ $158.22,157.92$, 155.69, 155.53, 131.42, 129.24, 122.58, 122.50, 120.83, 118.73, 111.85, 100.74, 100.30, 95.84, 55.87, 55.73, 25.87, 22.32, 17.75; IR (neat) 2840, 1567, 1489, 1405, 1170, 1106, $818 \mathrm{~cm}^{-1}$; LCMS (ESI) $m / z$ calcd for $\mathrm{C}_{22} \mathrm{H}_{25} \mathrm{O}_{4}[\mathrm{M}+\mathrm{H}]^{+}:$353.1753, found: 353.1768; Purity $98.30 \%$ (determined by RP-HPLC, method II, $t_{\mathrm{R}}=23.73 \mathrm{~min}$ ).

6-Methoxy-2-(3,5-dimethoxyphenyl)-7-(3-methylbut-2-enyl)benzofuran (9): $74 \mathrm{mg}$ (12\% yield) as a pale yellow solid: ${ }^{1} \mathrm{H}-\mathrm{NMR}\left(400 \mathrm{MHz}, \mathrm{CDCl}_{3}\right) \delta 7.33(\mathrm{~d}, J=8.8 \mathrm{~Hz}, 1 \mathrm{H}), 6.99(\mathrm{~d}, J=2.4 \mathrm{~Hz}$, $2 \mathrm{H}), 6.93(\mathrm{~s}, 1 \mathrm{H}), 6.86(\mathrm{~d}, J=8.8 \mathrm{~Hz}, 1 \mathrm{H}), 6.44(\mathrm{t}, J=2.4 \mathrm{~Hz}, 1 \mathrm{H}), 5.40(\mathrm{t}, J=1.6 \mathrm{~Hz}, 1 \mathrm{H}), 3.91$ 
(s, 3H), $3.87(\mathrm{~s}, 6 \mathrm{H}), 3.65(\mathrm{~d}, J=7.6 \mathrm{~Hz}, 2 \mathrm{H}), 1.91(\mathrm{~s}, 3 \mathrm{H}), 1.69(\mathrm{~s}, 3 \mathrm{H}) ;{ }^{13} \mathrm{C}-\mathrm{NMR}(100 \mathrm{MHz}$, $\left.\mathrm{CDCl}_{3}\right) \delta 161.03,155.11,154.94,154.24,132.65,131.72,122.80,122.09,117.89,113.70,108.05$, $102.64,101.88,101.86,100.42,56.72,56.69,55.44,55.42,25.82,22.93,17.84$; IR (neat) 2999, $2934,2831,1601,148,1283,1200,1147,1026,815 \mathrm{~cm}^{-1}$; LCMS (ESI) $\mathrm{m} / z$ calcd for $\mathrm{C}_{22} \mathrm{H}_{25} \mathrm{O}_{4}$ $[\mathrm{M}+\mathrm{H}]^{+}:$353.1753, found: 353.1770; Purity 97.66\% (determined by RP-HPLC, method I, $\left.t_{\mathrm{R}}=26.89 \mathrm{~min}\right)$.

6-Methoxy-2-(3,5-dimethoxy-4-(3-methylbut-2-enyl)phenyl)-7-(3-methylbut-2-enyl)benzofuran (10): $110 \mathrm{mg}\left(15 \%\right.$ yield) as a colourless gummy liquid: ${ }^{1} \mathrm{H}-\mathrm{NMR}\left(400 \mathrm{MHz}, \mathrm{CDCl}_{3}\right) \delta 7.30(\mathrm{~d}$, $J=8.8 \mathrm{~Hz}, 1 \mathrm{H}), 7.01(\mathrm{~s}, 2 \mathrm{H}), 6.90(\mathrm{~s}, 1 \mathrm{H}), 6.85(\mathrm{~d}, J=8.4 \mathrm{~Hz}, 1 \mathrm{H}), 5.41$ (quint, $J=1.6$ and $8.0 \mathrm{~Hz}, 1 \mathrm{H}), 5.20$ (quint, $J=1.6$ and $6.8 \mathrm{~Hz}, 1 \mathrm{H}), 3.90(\mathrm{~s}, 9 \mathrm{H}), 3.66(\mathrm{~d}, J=7.6 \mathrm{~Hz}, 2 \mathrm{H}), 3.37$ $(\mathrm{d}, J=7.2 \mathrm{~Hz}, 2 \mathrm{H}), 1.93(\mathrm{~s}, 3 \mathrm{H}), 1.78(\mathrm{~s}, 3 \mathrm{H}), 1.69(\mathrm{~s}, 3 \mathrm{H}), 1.67(\mathrm{~s}, 3 \mathrm{H}) ;{ }^{13} \mathrm{C}-\mathrm{NMR}(100 \mathrm{MHz}$, $\left.\mathrm{CDCl}_{3}\right) \delta 158.19,155.58,154.92,154.12,131.58,131.38,129.48,122.99,122.56,122.14,118.72$, 117.67, 113.58, 107.90, 100.88, 100.40, 56.70, 55.79, 25.86, 25.84, 22.98, 22.33, 17.80, 17.76; IR (neat) 2997, 2899, 2832, 1570, 1494, 1408, 1237, 1162, 1112, 1078, 802, $743 \mathrm{~cm}^{-1}$; LCMS (ESI) $m / z$ calcd for $\mathrm{C}_{27} \mathrm{H}_{33} \mathrm{O}_{4}[\mathrm{M}+\mathrm{H}]^{+}: 421.2379$, found: 421.2372 ; Purity $98.41 \%$ (determined by RP-HPLC, method II, $\left.t_{\mathrm{R}}=30.66 \mathrm{~min}\right)$.

7-(6-Hydroxybenzofuran-2-yl)-2,2-dimethylchroman-5-ol, Wittifuran D (11): To a stirred solution of $8(100 \mathrm{mg}, 0.28 \mathrm{mmol})$ in dry DCM $(4 \mathrm{~mL})$ at $-78{ }^{\circ} \mathrm{C}$ under nitrogen conditions was added dropwise 1- $\mathrm{M} \mathrm{BBr}_{3}$ solution in $\mathrm{CH}_{2} \mathrm{Cl}_{2}(1.4 \mathrm{~mL}, 1.42 \mathrm{mmol})$ and stirred at the same temperature for $2 \mathrm{~h}$, then room temperature for $1 \mathrm{~h}$. After completion of the reaction, the excess $\mathrm{BBr}_{3}$ was quenched by adding ice water at $0{ }^{\circ} \mathrm{C}$. The reaction mixture was warmed to room temperature and extracted with ethyl acetate 2 times. The combined organic layer was dried over $\mathrm{MgSO}_{4}$, filtered, and evaporated. The residue was purified by silica gel column chromatography (Hex:EtOAc $=7: 3, v / v)$ to afford compound 11 (50 mg, 60\% yield) as a white solid: ${ }^{1} \mathrm{H}-\mathrm{NMR}\left(400 \mathrm{MHz}, \mathrm{CDCl}_{3}\right) \delta 7.36(\mathrm{~d}, J=8.4 \mathrm{~Hz}, 1 \mathrm{H}), 6.97(\mathrm{br}, 1 \mathrm{H}), 6.89$ $(\mathrm{s}, 1 \mathrm{H}), 6.81(\mathrm{~s}, 2 \mathrm{H}), 6.75(\mathrm{~d}, J=8.8 \mathrm{~Hz}, 1 \mathrm{H}), 4.96(\mathrm{~s}, 2 \mathrm{H}), 2.69(\mathrm{t}, J=6.8 \mathrm{~Hz}, 2 \mathrm{H}), 1.84(\mathrm{t}$, $J=6.4 \mathrm{~Hz}, 2 \mathrm{H}), 1.36(\mathrm{~s}, 6 \mathrm{H}) ;{ }^{13} \mathrm{C}-\mathrm{NMR}\left(100 \mathrm{MHz}, \mathrm{CDCl}_{3}\right) \delta 155.54,155.24,155.04,154.13$, $153.42,129.72,122.90,121.08,111.94,108.85,106.17,102.42,100.91,98.23,74.32,32.04,26.65$, 17.00; IR (neat) 3391, 2969, 1634, 1561, 1492, 1422, 1207, 1120, $972 \mathrm{~cm}^{-1}$; LCMS (ESI) $\mathrm{m} / z$ calcd for $\mathrm{C}_{19} \mathrm{H}_{19} \mathrm{O}_{4}[\mathrm{M}+\mathrm{H}]^{+}: 311.1283$, found: 311.1284 ; Purity $96.20 \%$ (determined by RP-HPLC, method I, $\left.t_{\mathrm{R}}=15.93 \mathrm{~min}\right)$.

5-(6-Hydroxybenzofuran-2-yl)benzene-1,3-diol, Moracin M (2): $45 \mathrm{mg}$ (70\% yield from 7) as a white solid: ${ }^{1} \mathrm{H}-\mathrm{NMR}\left(400 \mathrm{MHz}, \mathrm{CD}_{3} \mathrm{OD}\right) \delta 7.33(\mathrm{~d}, J=8.8 \mathrm{~Hz}, 1 \mathrm{H}), 6.89(\mathrm{~s}, 1 \mathrm{H}), 6.88(\mathrm{~d}$, $J=2.0 \mathrm{~Hz}, 1 \mathrm{H}), 6.74(\mathrm{~d}, J=2.4 \mathrm{~Hz}, 2 \mathrm{H}), 6.71(\mathrm{dd}, J=2.0$ and $8.4 \mathrm{~Hz}, 1 \mathrm{H}), 6.23(\mathrm{t}, J=2.4 \mathrm{~Hz}$, $1 \mathrm{H}) ;{ }^{13} \mathrm{C}-\mathrm{NMR}\left(100 \mathrm{MHz}, \mathrm{CD}_{3} \mathrm{OD}\right) \delta 158.52,155.80,155.41,154.67,132.37,121.60,120.58$, 111.80, 102.46, 102.05, 100.78, 97.01; IR (neat) 3522, 3248, 1609, 1424, 1357, 1279, 1131, 997, 955, $802 \mathrm{~cm}^{-1}$; LCMS (ESI) $m / z$ calcd for $\mathrm{C}_{14} \mathrm{H}_{11} \mathrm{O}_{4}[\mathrm{M}+\mathrm{H}]^{+}:$243.0651, found: 243.0649; Purity $96.42 \%$ (determined by RP-HPLC, method $\mathrm{I}, t_{\mathrm{R}}=7.46 \mathrm{~min}$ ).

\subsubsection{General Procedure for Demethylation}

Powdered $\mathrm{NaOH}(254 \mathrm{mg}, 6.3 \mathrm{mmol})$ was added to a resealable tube containing aryl methyl ethers $(8,9$, and 10$)(0.7 \mathrm{mmol})$. The tube was evacuated with vacuum and filled back with $\mathrm{N}_{2}$ gas. Anhydrous NMP ( $2 \mathrm{~mL}$ ) was added to the mixture, followed by an addition of 1-dodecanethiol $(1 \mathrm{~mL}, 5.0 \mathrm{mmol})$. The reaction mixture was stirred at $130{ }^{\circ} \mathrm{C}$ until the aryl methyl ether was consumed, as monitored by TLC. After reaction completion, the mixture was allowed to cool to room temperature, then acidified with $1-\mathrm{N} \mathrm{HCl}$ and diluted with (Ethyl Acetate) EtOAc. The aqueous phase was extracted with EtOAc, and the combined organic layers were washed with water and brine, dried over $\mathrm{MgSO}_{4}$, filtered, and evaporated. The residue was purified by column chromatography (Hex:EtOAc $=6: 4$, $v / v$ ) to afford compounds 1 and 12-17.

5-(6-Hydroxy benzofuran-2-yl)-2-(3-methylbut-2-enyl) benzene-1,3-diol, Moracin C (1): $70 \mathrm{mg}$ (30\% yield) as a white solid: ${ }^{1} \mathrm{H}-\mathrm{NMR}\left(400 \mathrm{MHz}, \mathrm{CD}_{3} \mathrm{OD}\right) \delta 7.33(\mathrm{~d}, J=8.8 \mathrm{~Hz}, 1 \mathrm{H}), 6.88$ $(\mathrm{br}, 1 \mathrm{H}), 6.83(\mathrm{~s}, 1 \mathrm{H}), 6.78(\mathrm{~s}, 2 \mathrm{H}), 6.72(\mathrm{dd}, J=2.0$ and $8.4 \mathrm{~Hz}, 1 \mathrm{H}), 5.26(\mathrm{t}, J=6.4 \mathrm{~Hz}, 1 \mathrm{H})$, 
$3.32(\mathrm{~d}, J=6.4 \mathrm{~Hz}, 2 \mathrm{H}), 1.78(\mathrm{~s}, 3 \mathrm{H}), 1.67(\mathrm{~s}, 3 \mathrm{H}) ;{ }^{13} \mathrm{C}-\mathrm{NMR}\left(100 \mathrm{MHz}, \mathrm{CD}_{3} \mathrm{OD}\right) \delta$ 156.08, $155.68,155.15,155.05,129.89,128.79,122.92,121.75,120.35,115.40,111.64,102.33,99.83$, 96.97, 24.58, 21.89, 16.51; ${ }^{1} \mathrm{H}-\mathrm{NMR}\left(400 \mathrm{MHz},\left(\mathrm{CD}_{3}\right)_{2} \mathrm{CO}\right) \delta 7.36(\mathrm{~d}, J=8.4 \mathrm{~Hz}, 1 \mathrm{H}), 6.94$ $(\mathrm{d}, J=2.0 \mathrm{~Hz}, 1 \mathrm{H}), 6.89(\mathrm{~s}, 2 \mathrm{H}), 6.88(\mathrm{~d}, J=0.4 \mathrm{~Hz}, 1 \mathrm{H}), 6.78(\mathrm{dd}, J=2.0$ and $8.4 \mathrm{~Hz}, 1 \mathrm{H})$, $5.32-5.28(\mathrm{~m}, 1 \mathrm{H}), 3.37(\mathrm{~d}, J=6.8 \mathrm{~Hz}, 2 \mathrm{H}), 1.76(\mathrm{~s}, 3 \mathrm{H}), 1.63(\mathrm{~s}, 3 \mathrm{H}) ;{ }^{13} \mathrm{C}-\mathrm{NMR}(100 \mathrm{MHz}$, $\left.\left(\mathrm{CD}_{3}\right)_{2} \mathrm{CO}\right) \delta 156.24,155.74,155.54,154.86,130.08,128.96,123.06,121.75,120.90,115.34$, 112.14, 102.90, 100.52, 97.42, 24.99, 21.18, 17.00; IR (neat) 3332, 2916, 1612, 1489, 1436, 1039, 980, $830 \mathrm{~cm}^{-1}$; LCMS (ESI) $\mathrm{m} / z$ calcd for $\mathrm{C}_{19} \mathrm{H}_{19} \mathrm{O}_{4}[\mathrm{M}+\mathrm{H}]^{+}:$311.1283, found: 311.1288; Purity $98.17 \%$ (determined by RP-HPLC, method $\mathrm{I}, t_{\mathrm{R}}=14.32 \mathrm{~min}$ ).

2-(3-Hydroxy-5-methoxy-4-(3-methylbut-2-enyl)phenyl)benzofuran-6-ol, Artoindonesianin O (12): $33 \mathrm{mg}$ (14\% yield) as a white solid: ${ }^{1} \mathrm{H}-\mathrm{NMR}\left(400 \mathrm{MHz}, \mathrm{CD}_{3} \mathrm{OD}\right) \delta 7.33(\mathrm{~d}, J=8.4 \mathrm{~Hz}$, $1 \mathrm{H}), 6.92(\mathrm{~s}, 1 \mathrm{H}), 6.92(\mathrm{~s}, 3 \mathrm{H}), 6.73(\mathrm{dd}, J=1.6$ and $8.4 \mathrm{~Hz}, 1 \mathrm{H}), 5.20(\mathrm{t}, J=6.8 \mathrm{~Hz}, 1 \mathrm{H}), 3.86$ $(\mathrm{s}, 3 \mathrm{H}), 3.31(\mathrm{~d}, J=6.0 \mathrm{~Hz}, 2 \mathrm{H}), 1.76(\mathrm{~s}, 3 \mathrm{H}), 1.65(\mathrm{~s}, 3 \mathrm{H}) ;{ }^{13} \mathrm{C}-\mathrm{NMR}\left(100 \mathrm{MHz}, \mathrm{CD}_{3} \mathrm{OD}\right) \delta$ $160.14,157.23,157.16,156.75,156.43,131.45,130.55,124.25,123.23,121.91,118.13,113.20$, 105.33, 101.66, 99.65, 98.50, 56.18, 26.02, 23.25, 17.93; IR (neat) 3282, 2921, 1614, 1504, 1437, $1413,1359,1299,1282,1164,1141,1083,970,941,838,774 \mathrm{~cm}^{-1}$; LCMS (ESI) $\mathrm{m} / z$ calcd for $\mathrm{C}_{20} \mathrm{H}_{21} \mathrm{O}_{4}[\mathrm{M}+\mathrm{H}]^{+}: 325.1440$, found: 325.1445 ; Purity $99.58 \%$ (determined by RP-HPLC, method $\left.\mathrm{I}, t_{\mathrm{R}}=18.95 \mathrm{~min}\right)$.

2-(3,5-Dimethoxy-4-(3-methylbut-2-enyl)phenyl)benzofuran-6-ol (13): $24 \mathrm{mg}$ (10\% yield) as a half white solid: ${ }^{1} \mathrm{H}-\mathrm{NMR}\left(400 \mathrm{MHz}, \mathrm{CD}_{3} \mathrm{OD}\right) \delta 7.38(\mathrm{~d}, J=8.4 \mathrm{~Hz}, 1 \mathrm{H}), 7.02(\mathrm{bs}, 1 \mathrm{H})$, $6.98(\mathrm{~s}, 2 \mathrm{H}), 6.90(\mathrm{~s}, 1 \mathrm{H}), 6.77(\mathrm{dd}, J=2.0$ and $8.2 \mathrm{~Hz}, 1 \mathrm{H}), 5.20(\mathrm{t}, J=7.2 \mathrm{~Hz}, 1 \mathrm{H}), 4.91(\mathrm{~s}$, $1 \mathrm{H}), 5.91(\mathrm{~s}, 6 \mathrm{H}), 3.37(\mathrm{~d}, J=6.8 \mathrm{~Hz}, 2 \mathrm{H}), 1.78(\mathrm{~s}, 1 \mathrm{H}), 1.67(\mathrm{~s}, 3 \mathrm{H}) ;{ }^{13} \mathrm{C}-\mathrm{NMR}(100 \mathrm{MHz}$, $\left.\mathrm{CD}_{3} \mathrm{OD}\right) \delta 158.26,155.74,155.60,153.49,131.45,129.18,122.97,122.52,120.98,118.89,111.96$, 100.74, 100.43, 98.27, 55.91, 25.86, 22.35, 17.76; IR (neat) 3095, 2921, 2848, 1747, 1569, 1409, $1221,1104,962,827 \mathrm{~cm}^{-1}$; LCMS (ESI) $m / z$ calcd for $\mathrm{C}_{21} \mathrm{H}_{23} \mathrm{O}_{4}[\mathrm{M}+\mathrm{H}]^{+}: 339.1596$, found: 339.1599; Purity 99.15\% (determined by RP-HPLC, method I, $t_{\mathrm{R}}=23.80 \mathrm{~min}$ ).

5-(6-Hyroxy-7-(3-methylbut-2-enyl)benzofuran-2-yl)benzene-1,3-diol, Moracin S (14): $35 \mathrm{mg}$ (15\% yield) as a white solid: ${ }^{1} \mathrm{H}-\mathrm{NMR}\left(400 \mathrm{MHz}, \mathrm{CD}_{3} \mathrm{OD}\right) \delta 7.15(\mathrm{~d}, J=8.4 \mathrm{~Hz}, 1 \mathrm{H}), 6.87(\mathrm{~s}$, $1 \mathrm{H}), 6.76(\mathrm{~d}, J=1.6 \mathrm{H}, 2 \mathrm{H}), 6.70(\mathrm{~d}, J=8.0 \mathrm{~Hz}, 1 \mathrm{H}), 6.21(\mathrm{t}, J=2.0 \mathrm{~Hz}, 1 \mathrm{H}), 5.40(\mathrm{t}, J=7.6 \mathrm{~Hz}$, $1 \mathrm{H}), 3.58(\mathrm{~d}, J=7.2 \mathrm{~Hz}, 2 \mathrm{H}), 1.88(\mathrm{~s}, 3 \mathrm{H}), 1.68(\mathrm{~s}, 3 \mathrm{H}) ;{ }^{13} \mathrm{C}-\mathrm{NMR}\left(100 \mathrm{MHz}, \mathrm{CD}_{3} \mathrm{OD}\right) \delta 158.50$, $154.44,154.36,152.37,132.59,130.89,122.05,121.43,117.46,111.61,111.17,102.39,101.88$, 101.06, 24.54, 22.20, 16.68; IR (neat) 3338, 3192, 1645, 1480, 1422, 1134, 1036, $807 \mathrm{~cm}^{-1}$; LCMS (ESI) $m / z$ calcd for $\mathrm{C}_{19} \mathrm{H}_{19} \mathrm{O}_{4}[\mathrm{M}+\mathrm{H}]^{+}: 311.1283$, found: 311.1284 ; Purity $98.86 \%$ (determined by RP-HPLC, method $\mathrm{I}, t_{\mathrm{R}}=12.77 \mathrm{~min}$ ).

5-(6-Methoxy-7-(3-methylbut-2-enyl)benzofuran-2-yl)benzene-1,3-diol (15): $33 \mathrm{mg}$ (14\% yield) as a white solid: ${ }^{1} \mathrm{H}-\mathrm{NMR}\left(400 \mathrm{MHz}, \mathrm{CD}_{3} \mathrm{OD}\right) \delta 7.35(\mathrm{~d}, J=8.8 \mathrm{~Hz}, 1 \mathrm{H}), 6.88(\mathrm{bs}, 1 \mathrm{H}), 6.74$ $(\mathrm{dd}, J=2.0$ and $9.0 \mathrm{~Hz}, 1 \mathrm{H}), 6.70-6.69(\mathrm{~m}, 2 \mathrm{H}), 6.46(\mathrm{~d}, J=2.0 \mathrm{~Hz}, 1 \mathrm{H}), 5.09(\mathrm{t}, J=5.2 \mathrm{~Hz}$, $1 \mathrm{H}), 3.43(\mathrm{~d}, J=6.4 \mathrm{~Hz}, 2 \mathrm{H}), 2.96(\mathrm{~s}, 3 \mathrm{H}), 1.65(\mathrm{~s}, 6 \mathrm{H}) ;{ }^{13} \mathrm{C}-\mathrm{NMR}\left(100 \mathrm{MHz}, \mathrm{CD}_{3} \mathrm{OD}\right) \delta$ 158.94, 155.90, 155.64, 155.26, 154.43, 131.44, 130.10, 124.04, 121.49, 120.52, 119.29, 111.67, $106.59,104.41,98.83,96.95,54.65,25.13,24.45,16.60$; IR (neat) 2921, 2850, 1605, 1424, 1141, $1115,1042,979,817 \mathrm{~cm}^{-1}$; LCMS (ESI) $\mathrm{m} / z$ calcd for $\mathrm{C}_{20} \mathrm{H}_{21} \mathrm{O}_{4}[\mathrm{M}+\mathrm{H}]^{+}: 325.1440$, found: 325.1444; Purity 95.38\% (determined by RP-HPLC, method I, $t_{\mathrm{R}}=17.18 \mathrm{~min}$ ).

5-(6-Hyroxy-7-(3-methylbut-2-enyl)benzofuran-2-yl)-2-(3-methylbut-2-enyl)benzene-1,3-diol, Morusalfuran D (16): $35 \mathrm{mg}$ (15\% yield) as a white solid: ${ }^{1} \mathrm{H}-\mathrm{NMR}\left(400 \mathrm{MHz}, \mathrm{CD}_{3} \mathrm{OD}\right)$ $\delta 7.13(\mathrm{~d}, J=8.0 \mathrm{~Hz}, 1 \mathrm{H}), 6.80(\mathrm{~s}, 2 \mathrm{H}), 6.79(\mathrm{~s}, 1 \mathrm{H}), 6.69(\mathrm{~d}, J=8.4 \mathrm{~Hz}, 1 \mathrm{H}), 5.40(\mathrm{t}, J=7.2 \mathrm{~Hz}$, $1 \mathrm{H}), 5.25(\mathrm{t}, J=7.2 \mathrm{~Hz}, 1 \mathrm{H}), 3.58(\mathrm{~d}, J=7.6 \mathrm{~Hz}, 2 \mathrm{H}), 3.30(\mathrm{~d}, J=7.2 \mathrm{~Hz}, 2 \mathrm{H}), 1.86(\mathrm{~s}, 3 \mathrm{H})$, $1.76(\mathrm{~s}, 3 \mathrm{H}), 1.67(\mathrm{~s}, 3 \mathrm{H}), 1.65(\mathrm{~s}, 3 \mathrm{H}) ;{ }^{13} \mathrm{C}-\mathrm{NMR}\left(100 \mathrm{MHz}, \mathrm{CD}_{3} \mathrm{OD}\right) \delta 156.06,154.83,154.25$, $152.13,130.95,129.89,129.06,122.97,122.12,121.61,117.26,115.29,111.54,111.23,102.37$, 100.20, 24.61, 24.54, 22.22, 21.92, 16.73, 16.55; IR (neat) 3377, 2930, 1617, 1413, 1022, $\mathrm{cm}^{-1}$; LCMS (ESI) $\mathrm{m} / \mathrm{z}$ calcd for $\mathrm{C}_{24} \mathrm{H}_{27} \mathrm{O}_{4}[\mathrm{M}+\mathrm{H}]^{+}: 379.1909$, found: 379.1916 ; Purity $97.69 \%$ (determined by RP-HPLC, method I, $t_{\mathrm{R}}=18.93 \mathrm{~min}$ ). 
5-(6-Methoxy-7-(3-methylbut-2-enyl)benzofuran-2-yl)-2-(3-methylbut-2-enyl)benzene-1,3-diol (17): $33 \mathrm{mg}\left(14 \%\right.$ yield) as a white solid: ${ }^{1} \mathrm{H}-\mathrm{NMR}\left(400 \mathrm{MHz}, \mathrm{CDCl}_{3}\right) \delta 7.24(\mathrm{~d}, J=7.6 \mathrm{~Hz}, 1 \mathrm{H})$, $6.94(\mathrm{~s}, 1 \mathrm{H}), 6.92(\mathrm{~s}, 1 \mathrm{H}), 6.87(\mathrm{~s}, 1 \mathrm{H}), 6.76(\mathrm{~d}, J=8.4 \mathrm{~Hz}, 1 \mathrm{H}), 5.42(\mathrm{t}, J=7.6 \mathrm{~Hz}, 1 \mathrm{H}), 5.37$ $(\mathrm{s}, 1 \mathrm{H}), 5.29(\mathrm{~s}, 1 \mathrm{H}), 5.25(\mathrm{t}, J=7.2 \mathrm{~Hz}, 1 \mathrm{H}), 3.89(\mathrm{~s}, 3 \mathrm{H}), 3.71(\mathrm{~d}, J=7.2 \mathrm{~Hz}, 2 \mathrm{H}), 3.43(\mathrm{~d}$, $J=7.2 \mathrm{~Hz}, 2 \mathrm{H}), 1.09$ (s, 3H), $1.82(\mathrm{~s}, 3 \mathrm{H}), 1.77(\mathrm{~s}, 3 \mathrm{H}), 1.75(\mathrm{~s}, 3 \mathrm{H}) ;{ }^{13} \mathrm{C}-\mathrm{NMR}(100 \mathrm{MHz}$, $\left.\mathrm{CD}_{3} \mathrm{OD}\right) \delta 158.62,155.69,154.70,154.32,152.23,130.77,129.97,129.31,122.82,122.14,121.63$, 117.36, 116.53, 111.61, 111.18, 103.86, 100.51, 98.13, 54.69, 24.55, 24.54, 22.25, 21.79, 16.68, 16.47; IR (neat) 3273, 2913, 1620, 1492, 1416, 1223, 1165, 1092, $807 \mathrm{~cm}^{-1}$; LCMS (ESI) $\mathrm{m} / z$ calcd for $\mathrm{C}_{25} \mathrm{H}_{29} \mathrm{O}_{4}[\mathrm{M}+\mathrm{H}]^{+}$: 393.2066, found: 393.2063; Purity 99.73\% (determined by RP-HPLC, method I, $t_{\mathrm{R}}=23.94 \mathrm{~min}$ ).

Supplementary Materials: The supplementary materials are available online.

Author Contributions: W.J.C. designed and wrote the manuscript; J.N.M. and M.K.B. synthesized the compounds; and H.-S.C. performed the pharmacological experiments. All authors have read and agreed to the published version of the manuscript.

Funding: This research was funded by Dongguk University and the National Research Foundation of Korea (NRF).

Institutional Review Board Statement: Not applicable.

Informed Consent Statement: Not applicable.

Data Availability Statement: The data presented in this study are available on request from the corresponding author.

Acknowledgments: This study was supported by the research program of Dongguk University, 2018 and the Basic Science Research Program through the National Research Foundation of Korea (NRF) funded by the Ministry of Education (NRF-2017R1D1A1B03036116).

Conflicts of Interest: The authors declare no conflict of interest.

Sample Availability: Samples of the compounds are available from the corresponding author.

\section{References}

1. Yusuf, S.; Reddy, S.; Ounpuu, S.; Anand, S. Global burden of cardiovascular diseases: Part II: Variations in cardiovascular disease by specific ethnic groups and geographic regions and prevention strategies. Circulation 2001, 104, 2855-2864. [CrossRef]

2. Sung, K.C.; Kim, B.J.; Ryu, S. An association of a variety of cardiovascular risk factors with low grade albuminuria in Korean men. Atherosclerosis 2008, 196, 320-326. [CrossRef] [PubMed]

3. Lagace, T.A. PCSK9 and LDLR degradation: Regulatory mechanisms in circulation and in cells. Curr. Opin. Lipidol. 2014, 25, 387-393. [CrossRef] [PubMed]

4. Raal, F.; Scott, R.; Somaratne, R.; Bridges, I.; Li, G.; Wasserman, S.M.; Stein, E.A. Low-density lipoprotein cholesterol-lowering effects of AMG 145, a monoclonal antibody to proprotein convertase subtilisin/kexin type 9 serine protease in patients with heterozygous familial hypercholesterolemia: The reduction of LDL-C with PCSK9 inhibition in heterozygous familial hypercholesterolemia disorder (RUTHERFORD) randomized trial. Circulation 2012, 126, 2408-2417.

5. Catapano, A.L.; Pirillo, A.; Norata, G.D. New pharmacological approaches to target PCSK9. Curr. Atheroscler. Rep. 2020, $22,24$. [CrossRef]

6. Lintner, N.G.; McClure, K.F.; Petersen, D.; Londregan, A.T.; Piotrowski, D.W.; Wei, L.; Cate, J.H. Selective stalling of human translation through small-molecule engagement of the ribosome nascent chain. PLoS Biol. 2017, 15, e2001882. [CrossRef]

7. Nhoek, P.; Chae, H.S.; Masagalli, J.N.; Mailar, K.; Pel, P.; Kim, Y.-M.; Choi, W.J.; Chin, Y.-W. Discovery of flavonoids from Scutellaria baicalensis with inhibitory activity against PCSK 9 expression: Isolation, synthesis and their biological evaluation. Molecules 2018, 23, 504. [CrossRef]

8. Chae, H.S.; You, B.H.; Kim, D.Y.; Lee, H.; Ko, H.W.; Ko, H.-J.; Choi, Y.H.; Choi, S.S.; Chin, Y.-W. Sauchinone controls hepatic cholesterol homeostasis by the negative regulation of PCSK9 transcriptional network. Sci. Rep. 2018, 8, 6737. [CrossRef]

9. Ahn, J.; Kim, Y.M.; Chae, H.S.; Choi, Y.H.; Ahn, H.-C.; Yoo, H.; Kang, M.; Kim, J.; Chin, Y.-W. Prenylated flavonoids from the roots and rhizomes of Sophora tonkinensis and their effects on the expression of inflammatory mediators and proprotein convertase subtilisin/kexin type 9. J. Nat. Prod. 2019, 82, 309-317. [CrossRef] [PubMed]

10. Pel, P.; Chae, H.S.; Nhoek, P.; Kim, Y.M.; Chin, Y.-W. Chemical constituents with proprotein convertase subtilisin/kexin type 9 mRNA expression inhibitory activity from dried immature Morus alba fruits. J. Agric. Food Chem. 2017, 65, 5316-5321. [CrossRef] 
11. Arias, L.; Vara, Y.; Cossío, F.P. Regioselective preparation of benzo[b]furans from phenols and $\alpha$-bromoketones. J. Org. Chem. 2012, 77, 266-275. [CrossRef] [PubMed]

12. $\mathrm{Wu}, \mathrm{K} . ; \mathrm{Wu}, \mathrm{L} .-\mathrm{L} . ; \mathrm{Zhou}, \mathrm{C} .-\mathrm{Y} . ; \mathrm{Che}, \mathrm{C} .-\mathrm{M}$. Transition-metal-free $\mathrm{C}\left(\mathrm{sp}^{2}\right)-\mathrm{C}\left(\mathrm{sp}^{2}\right)$ cross-coupling of diazo quinones with catechol boronic esters. Angew. Chem. Int. Ed. 2020, 59, 16202-16208. [CrossRef] [PubMed]

13. Kitamura, T.; Otsubo, K. Palladium-catalyzed intramolecular hydroarylation of 6-benzofuranyl alkynoates. Heterocycles 2012, 86, 759-766. [CrossRef]

14. Weissman, S.A.; Zewge, D. Recent advances in ether dealkylation. Tetrahedron 2005, 61, 7833-7863. [CrossRef]

15. Tan, Y.-X.; Liu, C.; Chen, R.-Y. 2-arylbenzofuran derivatives from Morus wittiorum. Acta Pharm. Sin. 2008, 43, 1119-1122.

16. Chae, J. Practical demethylation of aryl methyl ethers using an odorless thiol reagent. Arch. Pharm. Res. 2008, 31, 305-309. [CrossRef]

17. Hakim, E.H.; Ulinnuha, U.Z.; Syah, Y.M.; Ghisalberti, E.L. Artoindonesianins N and O, new prenylated stilbene and prenylated arylbenzofuran derivatives from Artocarpus gomezianus. Fitoterapia 2002, 73, 597-603. [CrossRef]

18. Su, B.-N.; Cuendet, M.; Hawthorne, M.E.; Kardono, L.B.S.; Riswan, S.; Fong, H.H.S.; Mehta, R.G.; Pezzuto, J.M.; Kinghorn, A.D. Constituents of the bark and twigs of Artocarpus dadah with cyclooxygenase inhibitory activity. J. Nat. Prod. 2002, 65, 163-169. [CrossRef] [PubMed]

19. Ha, M.T.; Tran, M.H.; Ah, K.J.; Jo, K.-J.; Kim, J.; Kim, W.D.; Cheon, W.J.; Woo, M.H.; Ryu, S.H.; Min, B.S. Potential pancreatic lipase inhibitory activity of phenolic constituents from the root bark of Morus alba L. Bioorg. Med. Chem. Lett. 2016, 26, 2788-2794. [CrossRef] [PubMed]

20. McAllister, G.D.; Hartley, R.C.; Dawson, M.J.; Knaggs, A.R. Total synthesis of moracin C. J. Chem. Soc. Perkin Trans. 1998, 1, 3453-3457. [CrossRef]

21. Matsuyama, S.; Kuwahara, Y.; Nakamura, S.; Suzuki, T. Oviposition stimulants for the lesser mulberry pyralid, Glyphodes pyloalis (Walker), in mulberry leaves; Rediscovery of phytoalexin components as insect kairomones. Agric. Biol. Chem. 1991, 55, 1333-1341.

22. Wu, D.; Mei, H.; Tan, P.; Lu, W.; Zhu, J.; Wang, W.; Huang, J.; Li, J. Total synthesis of the 2-arylbenzo[b]furan-containing natural products from Artocarpus. Tetrahedron Lett. 2015, 56, 4383-4387. [CrossRef] 